\title{
Chronic Suppurative Osteomyelitis of the Mandible Treated with Antibiotics Complemented with Surgical Treatment: A Case Report
}

\author{
Osteomielitis Crónica Supurativa en Mandíbula Tratada \\ con Antibióticos y Cirugía: Reporte de Caso
}

\begin{abstract}
Víctor Hiram Barajas-Pérez; Norith de Jesús Recendez-Santillan²; María Elisa Vega-Memíje ${ }^{3}$; Alma Graciela García-Calderón ${ }^{4} \&$ Juan Carlos Cuevas-González ${ }^{4}$
\end{abstract}

BARAJAS-PÉREZ, V. H.; RECENDEZ-SANTILLAN, N. J.; VEGA-MEMÍJE, M. E. ; GARCÍA-CALDERÓN, A. G. \& CUEVAS-GONZÁLEZ, J. C. Chronic Suppurative Osteomyelitis of the Mandible Treated with Antibiotics Complemented with Surgical Treatment: A Case Report. Int. J. Odontostomat., 11(3):261-265, 2017.

ABSTRACT: Osteomyelitis is an infection that affects bone and bone marrow, it occurs due to inoculation of microorganisms either directly or by continuous accumulation through a hematogenous way. Female patient, 64 years old, presenting an increase of volume of the parotid masseteric region and right submandibular region, with approximately two weeks of evolution, which had a slightly fluctuating, hyperemic and hyperthermic indurated consistency; the patient complained of severe pain. CT scan and biopsy was indicated. It is imperative to identify the causative agent; the use of antibiotics must be complemented by surgical treatment to eliminate the possibility of a remaining infection.

KEY WORDS: chronic osteomyelitis, suppurative osteomyelitis, mandibular osteomyelitis.

\section{INTRODUCTION}

Osteomyelitis is an infection that affects bone and bone marrow. It occurs due to inoculation of microorganisms either directly or by continuous accumulation through a hematogenous way. Staphylococcus aureus is responsible for $50 \%$ of diagnosed cases in adults (Ugalde Ovares \& Morales Castro, 2014). The pathogenesis studied in animal models has shown that this microorganism uses adhesins to bind to fibronectin, laminin, collagen and osseous sialoglycoprotein. The pathogen binds to collagen and cartilage, and can survive intracellularly in osteoblasts, which is why the short-term treatments are ineffective (Leotau Rodríguez \& Alonso Villamizar, 2010). Most of the bacteria found in the bone tissue are phagocytosed by macrophages; however in poorly vascularized bone, macrophages do not reach the site of infection and inflammatory exudate occurs with an increase of intraosseous pressure between the cortical bone and bone marrow forming bone sequestration (Riu et al., 2009).

Osteomyelitis is classified as: chronic or acute suppurative osteomyelitis, chronic, focal or diffuse sclerosing osteomyelitis and Garre's osteomyelitis. The chronic diffuse sclerosing osteomyelitis has been mainly described in the mandible, which is characterized by a long history of recurrent pain and inflammation without suppuration; although the chronic suppurative osteomyelitis is less frequent, it usually arises as a complication of tooth extraction and generally occurs in adults (Miranda et al., 2011).

In the maxillofacial region the osteomyelitis occurs most often between the $5^{\text {th }}$ and 6 th decades of life, and it has been associated with systemic diseases. The mandible is more affected when compared to the maxila

\footnotetext{
${ }^{1}$ Faculty of Dentistry, Juárez University of Durango State. Durango, México.

${ }^{2}$ Faculty of Dentistry, University of Monterrey. Monterrey, Nuevo León, Mexico.

${ }^{3}$ Department of Dermatology, General Hospital “Dr. Manuel Gea González, México City, México

${ }^{4}$ Department of Stomatology, Institute of Biomedical Sciences. Autonomous University of Ciudad Juárez, Ciudad Juárez Chihuahua, México.
} 
due to the greater vascular supply in the cancellous bone, which hinders bacterial colonization, except from the frontal part where the contribution is yuxtaterminal which favors the formation of bone sequestration (Wintergerst et al., 2012). Clinically, the presence of a volume increase is evident as well as mobility of dental organs that are found in the area, pain, draining fistulas with intra or extra oral bone sequestration and pathological fractures (Oré Acevedo \& La Torre Caballero, 2013).

Treatment depends on the type of osteomyelitis, acute suppurative osteomyelitis usually respond to antibiotic therapy, in the case of chronic osteomyelitis, in addition to antibiotic therapy, it is necessary to complement the treatment with corticotomies, curettage, removal of bone sequestration or even large resections (Oré Acevedo \& La Torre Caballero). Here, we present the case report of a patient with chronic suppurative osteomyelitis of the mandible and the way she was treated, in order to share our experience and highlight the importance of correct diagnosis and treatment.

\section{CASE REPORT}

Female patient, 64 years old, with increase of volume of the right submandibular region, referring intense pain for approximately two weeks. Questioning revealed a history of rheumatoid arthritis, hypertension, allergies to multiple medications and autoimmune disorders with chronic use of corticosteroid. Physical examination revealed adynamia and deterioration of overall health, febrile illness and tumor in masseteric, parotid and right submandibular region. The region was indurated, slightly fluctuating, hyperemic and hyperthermic. The patient referred acute pain at palpation and trismus, with a mouth opening of about $10 \mathrm{~mm}$, chewing limitation and difficulty to take foods (Figs. $1 \mathrm{~A}$ and B).

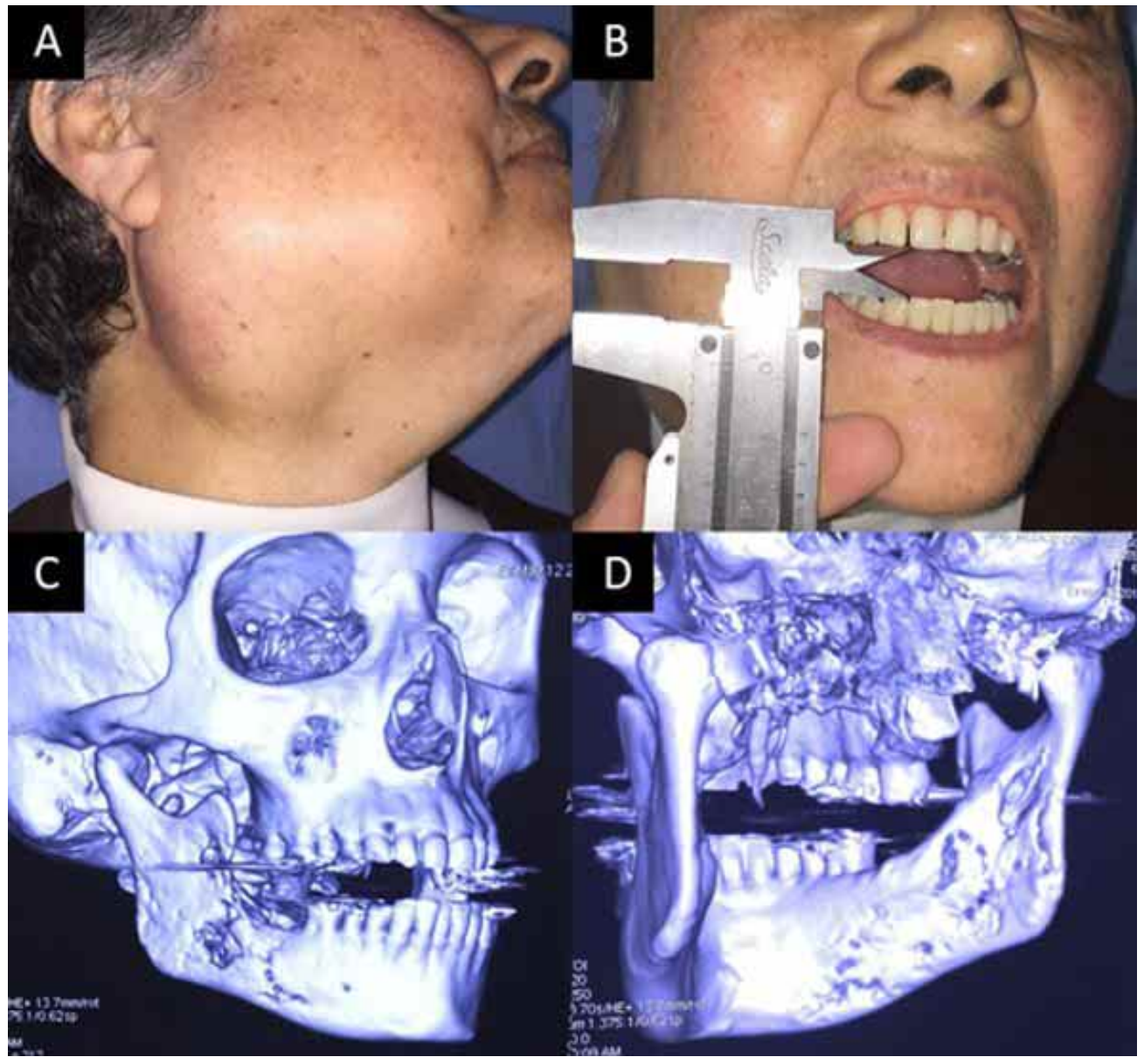

Fig. 1. (A) Side view, where a submandibular increased of volume of indurated consistency and fluctuate can be appreciated. (B) Limited mouth opening due to masseteric contracture, (C and D) CT scan with 3D reconstruction evidence osteolytic lesions in body and right mandibular branch. 
The patient had been previously treated by a dentist who prescribed broad-spectrum antibiotic (Clindamycin $600 \mathrm{mg}$ orally, every 6 hours for 7 days) with no favorable response, odontectomy was performed in dental organ 47 , evolving with increase of volume, severe pain, trismus, moderate odynophagia and fetid seropurulent secretion through the alveolar bed, reason by which she came to our service of maxillofacial surgery.

A computerized tomography scan was performed in our service which showed involvement of the cervicofacial submandibular, parotid, sublingual and lateral pharyngeal space, and multiple osteolytic areas that covered the body and ramus of the mandible with perforation of vestibular and lingual

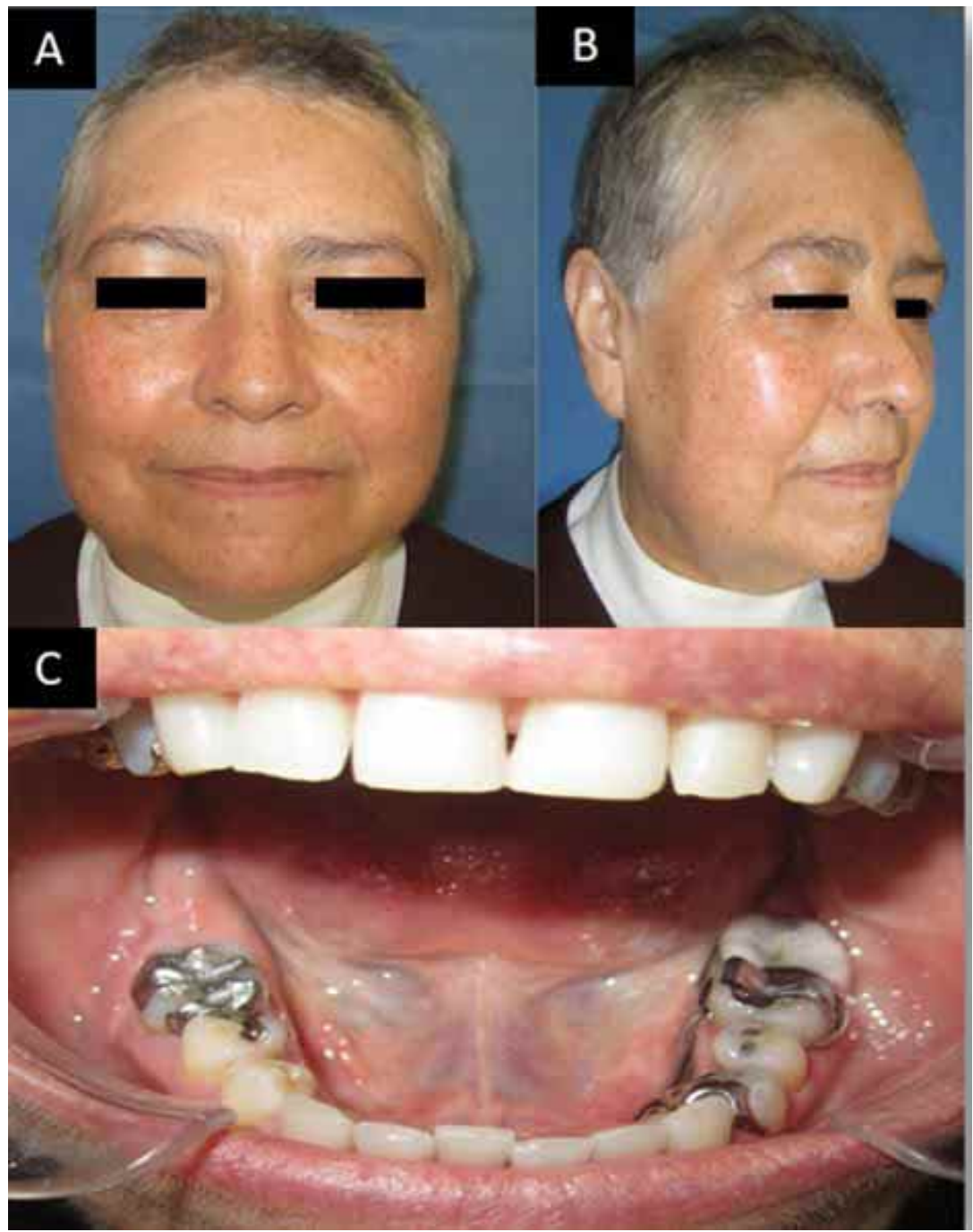

Fig. 2. Postoperative control at 4 months of treatment ( $A$ and $B)$, involution of the volume observed at the beginning of the treatment, $(C)$ mouth opening of about $25 \mathrm{~mm}$ and alveolar bed with proper healing (tooth 47 ). cortical data in the post extraction alveolar bed, with suggestive data of retained root remnant (Figs. $1 \mathrm{C}$ and D). Hospitalization of the patient was decided, to monitor airways and to apply antibiotic impregnation with Ceftriaxone $1 \mathrm{~g}$ IV every 24 hours, Clindamycin $600 \mathrm{mg}$ IV every 6 hours. Extraction of root remains was performed with local anesthesia. The sample for bacterial culture and antibiotic sensitivity testing was taken but no-bacterial growth was obtained which is attributed to the use of chronic antibiotic therapy. Debridement and abscess drainage with washing and curettage of the bone was performed in a second surgical event, incisional biopsy was taken obtaining a bone fragment at the site of the lesion, subsequently surgical washes every 12 hours for 5 days were performed, at her discharge from hospital we prescribed her oral broad-spectrum antibiotic therapy for long time (Moxifloxacin $400 \mathrm{mg}$ every 24 hours).

We observed fibrous connective tissue with a mixed type inflammatory infiltrate, predominance of macrophages, lymphocytes, plasma cells and necrotic trabecular bone at the histopathological study, so that the diagnosis of chronic suppurative osteomyelitis was confirmed. Due to the diagnosis, it was decided to continue the antibiotic treatment for 3 months keeping a close monitoring of the patient. After 4 months, a significant improvement of the overall health of the patient was observed, afebrile, with remission of submandibular volume increase, properly tolerating the oral track, without trismus data, intraorally alveolar bed was observed with appropriate healing without any secretion (Fig. 2). Almost a year after, the normalization of the trabecular bone was achieved (Fig. 3). 


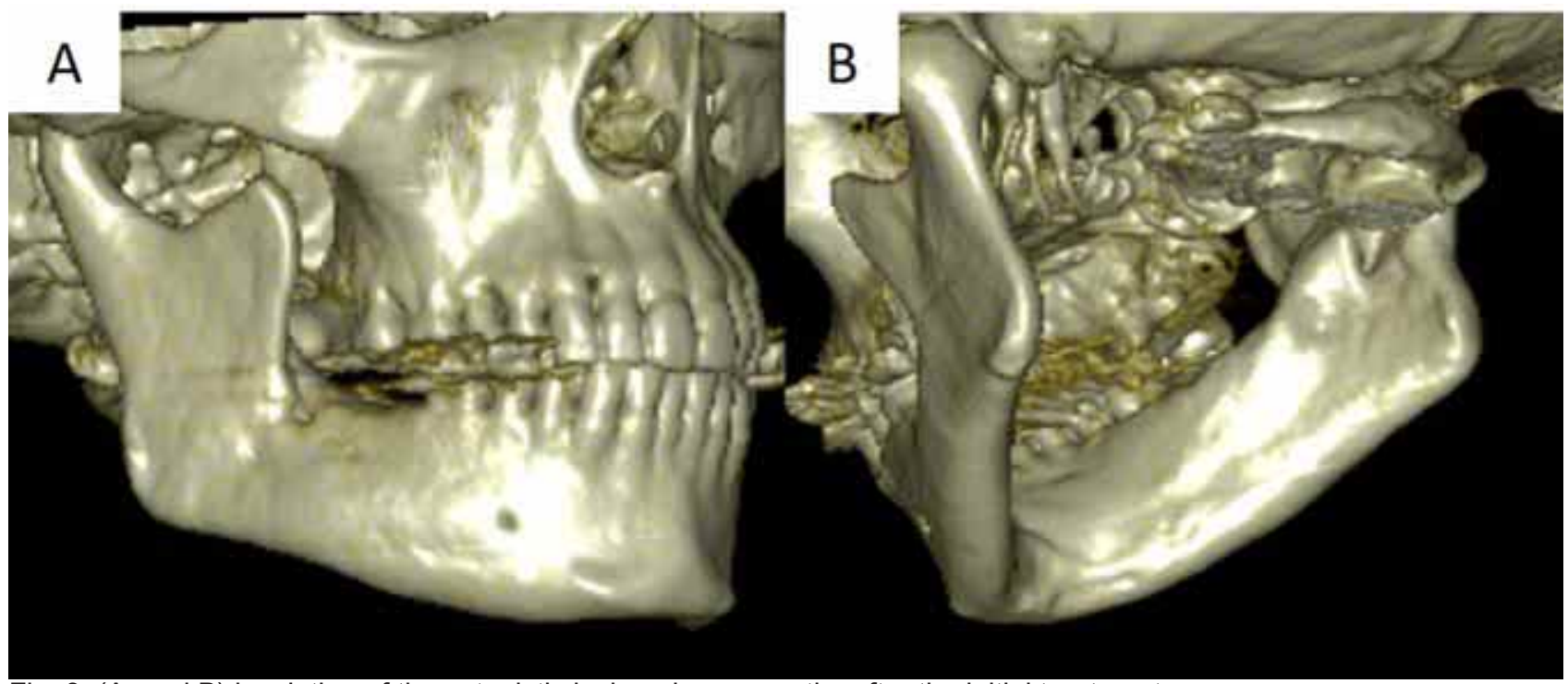

Fig. 3. (A and $B$ ) involution of the osteolytic lesion eleven months after the initial treatment.

\section{DISCUSSION}

Chronic osteomyelitis is a bone disease that is characterized by an inflammatory process which includes necrosis of bone marrow, suppuration, resorption, sclerosis and hyperplasia, its primary cause is microbiological and may be the result of dental infections, inadequate removal of necrotic bone, improper or inadequate antibiotic therapy of trauma (Mehra et al., 2013). It is not known with precision when the osteomyelitis changed from acute to chronic; the patient had gone to the doctor two weeks before for dental extraction where a root remain was left, the time of evolution of odontogenic infection at the time of the first dental visit is unknown.

Due to its physiopathology osteomyelitis is difficult to treat. When it occurs in adults, it is usually refractory to therapy. Patients with comorbidities such as uncontrolled diabetes, those patients with immunosuppressive therapy and those who have received radiation therapy have a higher risk of developing it (Yadav et al., 2014), in this case the patient had rheumatoid arthritis and was treated with corticosteroids, and her general health conditions were not optimal.

The main clinical features related to chronic osteomyelitis are: pain, bone exposure, increase of volume, suppuration, among others (Mallikarjun et al., 2011), when the patient came to our service, she showed an increase of volume, intense pain at palpation, impairment of the general condition, fever and trismus, therefore because of the information obtained in clinical records and examination we determined to use imaging studies.

With regard to complementary tests, plain radiography allowed us to observe new bone formation, bone destruction and loss of trabecular structure, which in adults takes 2 weeks from the beginning of infection to be visible, when about $50 \%$ of the mineral content has been lost in adults, and takes seven days in children (Ugalde Ovares \& Morales Castro). Computed tomography helps us to identify edema, spinal cord injury, periosteal reaction, cortical destruction and soft tissue affectation even though they are not visible on plain radiographs (Riu et al.), although computed tomography is not always accessible, we suggest at least the use of plain radiography to perform the clinical, radiographic and histopathological correlation and be certain of the diagnosis.

Most of the infectious processes in the oral and maxillofacial region are caused by various anaerobic bacteria, and cultivation is not possible in all cases (Goda et al., 2014). The result of cultures in this case was negative, possibly because the patient had been previously medicated. In chronic osteomyelitis, the treatment involves the prescription of antibiotics in combination with surgical debridement (Rajkumar et al., 2010). 
BARAJAS-PÉREZ, V. H.; RECENDEZ-SANTILLAN, N. J.; VEGA-MEMíJE, M. E. ; GARCíA-CALDERÓN, A. G. \& CUEVAS-GONZÁLEZ, J. C. Chronic Suppurative Osteomyelitis of the Mandible Treated with Antibiotics Complemented with Surgical Treatment: A Case Report. Int. J. Odontostomat., 11(3):261-265, 2017.

When the Staphylococcus aureus is the probable microorganism responsible of the infection, treatment consists of: Nafcillin or Oxacillin $2-12 \mathrm{mg} /$ day IV, every 4 hours with or without aminoglycoside; Vancomycin 1-2 mg/day, IV, every 12 hours with or without aminoglycoside; Clindamycin 1.8-2.7 mg/day, IV, every 8 hours with or without aminoglycoside (Reyes et al., 2001). Topazian et al. (2002) recommend the use of antimicrobial treatments for prolonged periods of time mainly with Beta-Lactams, Clindamycin and Metronidazole.

It has been suggested the intravenous use of antibiotics (3-10 days) at the beginning of the infection, and after a good response has been obtained to switch to oral treatment (4-6 weeks) until completing 6 months (Reyes et al.). The patient that we attended had already been medicated with Clindamycin for 2 weeks, however, there were root remains, therefore the infection remained latent. To avoid microbial resistance, we decided to use Moxifloxacin for 3 months obtaining good results, therefore we consider that each patient must be individually assessed to determine the proper treatment. In conclusion for the proper diagnosis of chronic osteomyelitis, a clinical, radiographic and histopathological correlation should be performed. It is imperative to identify the causative agent and the use of antibiotics should be complemented with surgical treatment and long-term follow-up to eliminate the possibility of a remaining infection.

BARAJAS-PÉREZ, V. H.; RECENDEZ-SANTILLAN, N. J.; VEGA-MEMÍJE, M. E.; GARCÍA-CALDERÓN, A. G. \& CUEVAS-GONZÁLEZ, J. C. Osteomielitis crónica supurativa en mandíbula tratada con antibióticos y con procedimiento quirúrgico: Reporte de Caso. Int. J. Odontostomat., 11(3):261265, 2017.

RESUMEN: La osteomielitis es un proceso infeccioso que afecta al hueso y medula ósea y que se produce debido a la inoculación de microorganismos ya sea de manera directa, por continuidad o bien por medio de la vía hematógena. Paciente femenino de 64 años de edad que presentaba aumento de volumen en región submandibular derecha refiriendo dolor intenso con evolución de 2 semanas aproximadamente, el cual era de consistencia indurada ligeramente fluctuante, hiperémico e hipertérmico; la paciente se quejaba de dolor intenso, se indicó TC y biopsia. En estos casos para tener éxito en el tratamiento el uso de antibióticos debe complementarse con desbridamiento quirúrgico, aunado a un seguimiento estrecho para descartar la posibilidad de una infección remanente.

PALABRAS CLAVE: osteomielitis crónica, osteomielitis supurativa, osteomielitis mandibular.

\section{REFERENCES}

Goda, A.; Maruyama, F.; Michi, Y.; Nakagawa. I. \& Harada, K. Analysis of the factors affecting the formation of the microbiome associated with chronic osteomyelitis of the jaw. Clin. Microbiol. Infect., 20(5):0309-17, 2014.

Leotau Rodríguez, M. A. \& Alonso Villamizar, H. Osteomielitis: Una revisión de la literatura. Rev. Univ. Salud, 1(12):135-45, 2010.

Mallikarjun, K.; Kohli, A.; Kumar, A. \& Tanwar, A. Chronic suppurative osteomyelitis of the mandible. J. Indian Soc. Pedod. Prev. Dent., 29(2):176-9, 2011.

Mehra, H,; Gupta, S.; Gupta, H.; Sinha, V. \& Singh, J. Chronic suppurative osteomyelitis of mandible: a case report. Craniomaxillofac. Trauma Reconstr., 6(3):197-200, 2013.

Miranda, V. E.; Carrillo, T. E.; Wong, R. G.; Picco, D. M. I. \& Arce, F. G. D. Osteomielitis supurativa crónica de la mandíbula. Reporte de un caso. Rev. Mex. Cir. Bucal Maxilofac., 7(3):92-7, 2011.

Oré Acevedo, J. F. \& La Torre Caballero, M. Pediatric maxillary and mandibular osteomyelitis. Acta Med. Peru., 30(4):86-90, 2013.

Rajkumar, G. C.; Hemalatha, M.; Shashikala, R. \& Kumar, D. V. Recurrent chronic suppurative osteomyelitis of the mandible. Indian J. Dent. Res., 21(4):606-8, 2010.

Reyes, R. H.; Navarro, R. P.; Jiménez, L. E. \& Reyes, B. H. Osteomielitis: Revisión y Actualización. R. F. M., 24(1):47-54, 2001.

Riu, L. M.; Pérez Quirós, M.; Rodríguez Romero, C. \& Raya, M. A. Tratamiento farmacológico de la osteomielitis. El Peu, 29(1):308, 2009.

Topazian, R.; Goldberg, H. \& Huup, J. R. (Eds.). Oral and Maxilofacial Infections. $4^{\text {th }}$ ed. Philadelphia, W. B. Saunders, 2002.

Ugalde Ovares, C. E. \& Morales Castro, D. Osteomielitis. ASOCOMEFO, 31(1):1-9, 2014.

Wintergerst, F. A.; Iturralde, E. C. J.; De la Riva, P. V. \& Reinoso, Q. S. Osteomielitis crónica maxilar. Informe de 4 casos clínicos. Rev. Odontol. Mex., 16(2):105-11, 2012.

Yadav, S.; Malik, S.; Mittal, H. C. \& Puri, P. Chronic suppurative osteomyelitis of posterior maxilla: A rare presentation. J. Oral Maxillofac. Pathol., 18(3):481, 2014.

Corresponding author:

Juan Carlos Cuevas González

Department of Stomatology

Institute of Biomedical Sciences

Autonomous University of Ciudad Juarez

Anillo Envolvente del Pronaf s/n, Zona Pronaf,

32315 Cd Juárez

Chihuahua

MEXICO

E-mail: juan.cuevas@uacj.mx

Received: 16-03-2017

Accepted: 19-06-2017 